\title{
Design of Vernis Sprayer Using Macroergonomic Analysis and Design
}

\author{
${ }^{1}$ Anjas Tambunan, ${ }^{2}$ Erwin Rozer Sitanggang, ${ }^{3}$ Anggianika Mardhatillah \\ Departement of Industrial Enginering Faculty of Technology and Science Prima Indonesia University \\ Email: tambunananjas@gmail.com
}

\begin{abstract}
The process of spraying varnish is an important part of this industry but it still uses minimal tools so that this process has several obstacles, namely wasted time, unreliable work positions, frequent defects, and disturbed other work stations. To overcome this, a varnish sprayer has been designed, but there are still many things that need to be improved in terms of shape. The research was conducted at SMEs AAT RATTAN CHANDY CRAFT which is engaged in rattan handicrafts such as chairs, tables, serving covers. From the data obtained, 21 out of 28 people experienced complaints in the arms and hands due to less ergonomic work positions and tools. This study uses the Macroergonomic Analysis and Design method, in order to obtain a varnish spray design proposal in the form of a rectangular, faceted iron frame, the main drive of the dynamo (motor), the belt rope as a power connector, the conveyor as a spraying route, the spray gun as a sprayer. The dimensions of this varnish sprayer are $230 \mathrm{~cm}$ high, $200 \mathrm{~cm}$ wide and $500 \mathrm{~cm}$ long. In the proposed working method, there must be two operators, the first operator at the input door of the lifting tool and putting the product on the conveyor, the second operator receiving at the output door of the tool. This eliminates bending and squatting activities because the conveyor height is made as high as $137 \mathrm{~cm}$ from the floor surface.
\end{abstract}

Keywords: Design, Spray Tool, Ergonomics, MEAD.

\section{INTRODUCTION}

Aat rattan handy craft is an SME that produces handi crafts from rattan as a basic ingredient located at JL Gatot Subroto, Titi Papan, Medan. The home industry for the manufacture of chairs, tables, serving covers, baskets from rattan is still using the manual varnishing process, resulting in various constraints affecting worker productivity. Worker productivity depends on work tools and worker performance so that to increase productivity, worker tools that support performance are needed. From the information obtained from the manufacturer, they often experience injuries to the parts of the hands, arms and waist caused by less ergonomic work positions and tools.

In the initial observation there are several aspects that are considered such as human resources, work environment, dimensions of work tools, and work systems. From the observations that have been made in the field, the finishing process uses a brush and a spray gun which results in the act of turning the product back and forth so that the varnish is evenly distributed in the field. rattan surface and of course this will take about 20 minutes for one unit of production because it is done manually and is less efficient.

Another factor that affects performance is worker fatigue where the level of speed, energy will appear to be reduced and increased emotions and annoyance so that there is a lack of tolerance towards other people which is caused by an unergonomic work position. This excess movement can cause complaints that cause common symptoms in the form of muscle aches. To be able to directly help the manufacturing process, Macroergonomics can also be used in the design approach to design work tools that can help performance. Research by Angga Haripurna, and Hary Purnomo, (2017) designed a soybean screening tool with the Macroergonomic Analysis and Design (MEAD) method which conducted research at Sumbermulyo Wonosari in a home industry that produced a soybean filtering tool in the process of making tofu. 
The research that was conducted found several indications of disturbances in the finishing or finishing process. Parts of the body that are overloaded, especially in the arms, are tools that are often damaged, often cause air pollution and disturb other work stations. From this background, this research was conducted to improve the work system by designing a varnish sprayer with a macroergonomic approach.

\section{LITERATURE REVIEW \\ 1 ERGONOMY}

Ergonomics comes from the Latin language, namely ERGON (work) and NOMOS (natural law) and can be defined as the human aspects of the work environment that are reviewed from anatomy, physiology, engineering, management and design design.

Ergonomics is also concerned with optimization, efficiency, health, safety and human comfort in the workplace. In ergonomics, a study of the system where humans or human resources, work facilities and their environment interact with each other is needed with the main objective of adjusting the working atmosphere with the human being.

\section{ANTHROPOMETRY}

According to Johan Dwi Purnomo, 2019, anthropometry is a field of science that deals with the dimensions of the human body. This dimension is divided into several parts, namely, the statistics group and the percentile size. For example, if 100 people stand parallel from the smallest to the largest in one sequence, this can be classified from 1 percentile to 100 percentile, in terms of product design with the aim of finding compatibility between uses, anthropometric data works on all the tools or products used. design can be adjusted according to the dimensions of the body and the capabilities of non-human humans that are adjusted by means of a tool.

\section{METHODOLOGY}

This research was conducted at UKM AAT RATTAN HANDY CRAFT on Jalan Gatot Subroto, Gang youth sei goat D. Medan Petisah, Medan. With a total sample of 28 people in the production with total sampling method.

In the initial stage, interviews were conducted with industry owners and gave questionnaires to all samples as the main resource persons and observations to find out the problems that existed in the industry. Anthropometric measurements of workers for the dimensions of upright height, standing eye height, standing shoulder height, standing elbow height, forward hand reach . At this stage, a design is carried out using macroergonomic analysis and design (MEAD).

The design steps using MEAD define organizational subsystems and responsibilities, environment and organization; defines the work system type and specifies its performance level desired; define operating units and work processes; identify variations in unit operations; create a variance matrix; analyzing the roles of personnel; allocating functions and combining designs and implementing.

\section{RESULTS AND DISCUSSION}

1. Definition of the organizational subsystem

creating products that prioritize the durability of the product itself rather than the appearance of the product, The organizational structure of the SMEs for rattan handy craft already has an organization consisting of industrial owners, industrial workers and sellers of rattan (raw material), where one factor is interrelated with other factors.

The duties and responsibilities of the owner also play a role as manager, 28 workers are responsible for completing the production process, and rattan sellers who have established partnerships with rattan handy craft are responsible for providing rattan. The work system in the rattan industry is highly dependent on the work tools used. Based on the results of the interview, a tool that is quite influential is the varnish spraying tool where this process is the final stage, but the tools used are still manual, and it is hoped that more practical tool updates will be available.

2. This type of rattan industrial production work system is an intermittent process with an irregular allocation of workers in defining responsibilities. Each process is separate from other processes. The 
intermittent process type of production work has a longer operating cycle time than the production operation cycle time of the continuous process. Thus, the hope of the production work system is to make it a continuous process, so that the process does not require transportation time and accelerates the production process.

3. Define the operating unit and work process

In the production process at UKM Aat rattan handy craft, there are three units of tools used, consisting of cutting, bending, and varnishing and those with too many deviations are varnish and this can be seen in table 2 .

The work processes in the rattan industry are, in sequence, cutting rattan, scraping the skin, bending, forming frames, weaving, sanding, grinding, drying. In this process, the heaviest job is the varnishing process. because the polishing process requires turning the object over and over to get an even polish. The complaint that often occurs is that workers complain about the skeletal muscles. Workers feel pain, especially in the arms, hands and waist.

4. Identification of variations

In this study, the focus is on the part of spraying varnish, work systems and work facilities that are still not ergonomic as shown in Figure 1.

In the work position data, it can be concluded that ergonomic considerations related to work position (spraying) are very important in terms of spraying varnish, because work position greatly affects the resistance of the worker's body, so that the results of the finishing process can get good quality and quantity. According to research data at UKM AAT RATTAN HANDY CRAFT, from 28 respondents said that standing is a comfortable position when doing the spraying process, a scale of 22 people or $78 \%$ for a standing position and 20 people or $71 \%$ for a sitting position. See table 1.

For certain things, a person must be able and free enough to adjust his body in order to obtain a more comfortable working attitude and position, especially when spraying varnish. Standing and sitting do not cause excessive frequency of activity for a long period of time. In a standing or sitting position, the hands or arms of workers are not above the normal elbow level.

Table 1: job position data

\begin{tabular}{|l|l|l|l|l|l|l|}
\hline Work position & 1 & 2 & 3 & 4 & 5 & Agree \\
\hline Stand up & 2 & 20 & 5 & 1 & & $78 \%$ \\
\hline Sit & & 20 & 4 & 3 & 1 & $71 \%$ \\
\hline Squat & & 4 & 4 & 20 & & $14 \%$ \\
\hline
\end{tabular}

The data obtained regarding the tools expected in the varnish spraying process are as follows:

Table 2: data tools used

\begin{tabular}{|l|l|l|l|l|l|l|}
\hline Variants & $\mathbf{1}$ & $\mathbf{2}$ & $\mathbf{3}$ & $\mathbf{4}$ & $\mathbf{5}$ & Agree \\
\hline Light & & 20 & 6 & 2 & & $71 \%$ \\
\hline Strong & 1 & 27 & & & & $99 \%$ \\
\hline Multifunction & 1 & 23 & 2 & 2 & & $82 \%$ \\
\hline Easy to use & 1 & 24 & 3 & & & $85 \%$ \\
\hline Does not cause excessive activity & 4 & 19 & 5 & & & $67 \%$ \\
\hline Fast & 3 & 19 & 6 & & & $67 \%$ \\
\hline Does not pollute the air & 4 & 19 & 5 & & & $67 \%$ \\
\hline Save energy and materials & 2 & 23 & 3 & & & $82 \%$ \\
\hline Can be used by all workers / employees & & 6 & 9 & 12 & 1 & $21 \%$ \\
\hline Where 1: strongly agree disagree & 2: agree & & & \\
\hline
\end{tabular}




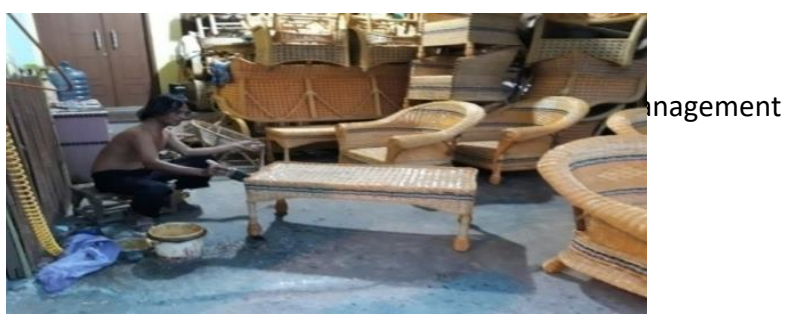

Figure 1: work position 1

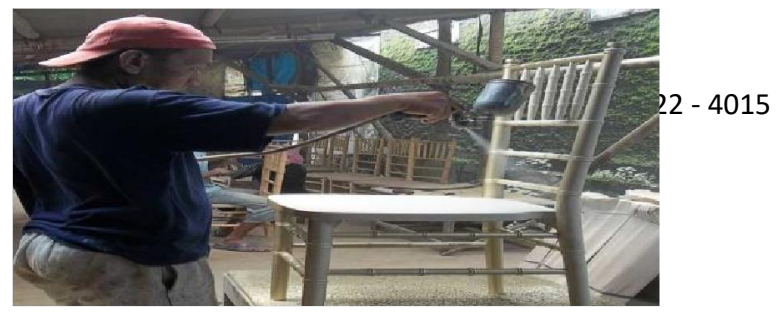

Figure 2: work position 2

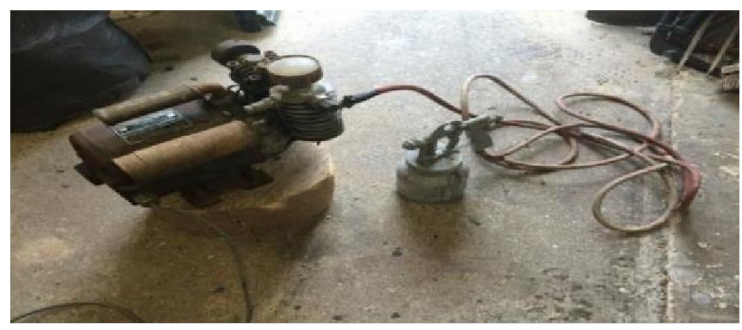

Figure 3: old work tool

5. Allocating functions and combining dimensions

Ergonomic aspects in a design are very important factors. Anthropometric data is used as a basis for consideration in determining the size of the dimensions of the work tool to be designed, which relates to human limbs as users.

In anthropometric data processing, data is used in the form of percentiles. Percentiles represent the number of parts per hundred of a population that have a specific body data. This percentile is important to get the percentage of the sample that will be accommodated against the designed tool.The previous description tool, then the new varnish sprayer is designed based on the anthropometric percentage data below.

The design of this sprayer was made based on the needs and convenience of 28 samples in the AAT RATTAN HANDY CRAFT and calculated with the 5th percentile, this is done so that respondents with small body dimensions can use this tool and respondents with large body dimensions adjust. The average of the anthropometric data is as follows;

Table 3: average anthropometric data

\begin{tabular}{|l|l|}
\hline Variants & Average \\
\hline dimensions of upright height & $163,6 \mathrm{~cm}$ \\
\hline standing eye height & $152 \mathrm{~cm}$ \\
\hline standing shoulder height & $143 \mathrm{~cm}$ \\
\hline standing elbow height & $101 \mathrm{~cm}$ \\
\hline forward hand reach & $61,4 \mathrm{~cm}$ \\
\hline
\end{tabular}

$$
\mathrm{P}=\overline{\mathrm{X}}+\mathrm{K}(\mathrm{S})
$$

where: $\quad \overline{\mathrm{X}}=$ Average value

$\mathrm{K}=$ General values carried out in the design $(1,645)$

$\mathrm{S}=$ Standard intersection $9,02 \mathrm{~cm}$

5 th percentile of shoulder height

$$
\begin{aligned}
\mathrm{P} & =143-\mathrm{k}(9,02) \quad=143-1,645(9,02) \\
& =128 \mathrm{~cm}
\end{aligned}
$$

then the conveyor height in the tool design is $128 \mathrm{~cm}$.

5 th percentile forward hand reach

$$
\begin{aligned}
\mathrm{p} & =61,5-\mathrm{k}(9,02) \quad=61,5-1,645(9,02) \\
& =46,66 \mathrm{~cm}
\end{aligned}
$$

So for the operator's hand reach to the position of the object on the runway is $47 \mathrm{~cm}$ and the conveyor height is $128 \mathrm{~cm}$ from the floor base so that the height of the body is above the average that adjusts. 


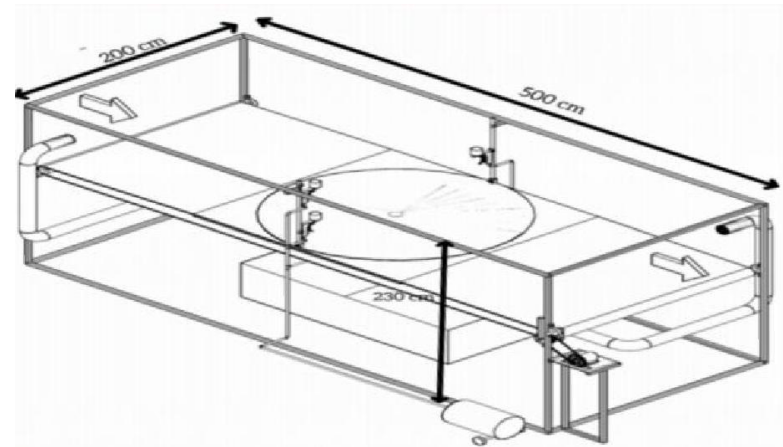

Figure 4: side view design

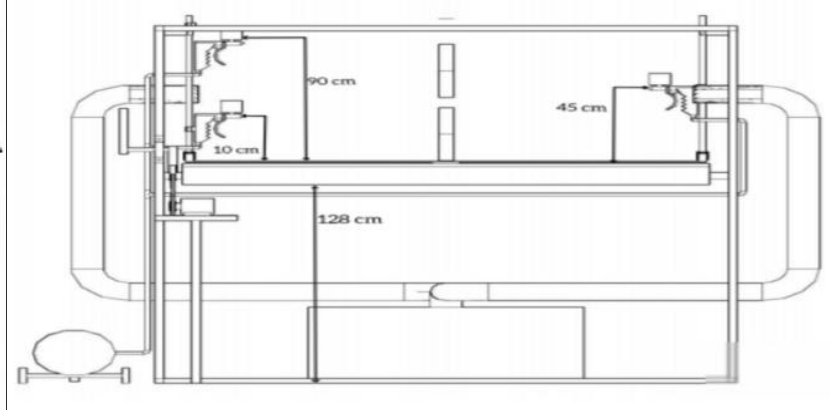

Figure 5: front view design

The shortage of old tools is that they are too heavy because they have to be used by hand directly, with a spray gun tube diameter of $11 \mathrm{~cm}$, so for long-term use this will cause complaints to certain parts of the body. The new tool design still uses a spray gun but what distinguishes it is that the spray gun is placed in a box with a size of $230 \mathrm{~cm}$ high, $200 \mathrm{~cm}$ wide and $500 \mathrm{~cm}$ long and given a conveyor as a moving floor or moving product driven by a dynamo ( motorcycle). With a conveyor height of $128 \mathrm{~cm}$ from the floor of the appliance, this measurement is based on the average shoulder height of all respondents.

\section{CONCLUSION}

The process of spraying varnish is a process that has the highest load and absorbs a lot of energy so that a new tool design is needed. The proposed new tool design by innovating a spraying device by adding a dynamo and conveyor so that workers do not need to use other tools. In this design a spray box is placed on three spray guns, namely A1 on the right with a height of $90 \mathrm{~cm}$ from the conveyor surface, A2 is below A1 with a height of $10 \mathrm{~cm}$, and B1 is on the left with a height of $45 \mathrm{~cm}$ from the conveyor surface. .

\section{REFERENCE}

[1] Andriani, Meri dan Subhan .2016. Perancangan Peralatan Secara Ergonomi Untuk Meminimalkan Kelelahan Di Pabrik Kerupuk. semnastek.

[2] Haripurna, Angga dan Hari Purnomo.2017.Desain Perancangan Alat Penyaring Dalam Proses Pembuatan Tahu Dengan Metode Macroergonomic Analysis And Design. Jiti, 16, 1.

[3] Iridiastadi,Hardianto. 2017. Ergonomi Suatu Pengantar.Bandung: Remaja Rosdakarya.

[4] Iriani,Ismail. 2016. Pengaruh kelengkapan alat kerja dan displin kerja terhadap kinerja karyawan.JSBM,03, 1 .

[5] Nurmianto,Eko.2008. Ergonomi Konsep Dasar dan Aplikasinya. Surabaya: Guna Widya.

[6] Pratama, Antonius Hari dan Heri Setiawan.2020. Perancanan Alat Bantu Memasukkan Ergonomi Ke Dalam Karung.JEI.06.1.

[7] Tambunan,Mangara M. Dini W., dan Joseph K. 2016.Perancangan Fasilitas Kerja Di Bagian Produksi Dengan Menggunakan Macroergonomic Analysis Design. Jurnal teknik industri,18,1.

[8] Wignjosoebroto, Sritomo. 2008. Ergonomi Studi Gerak dan Waktu. Surabaya: Guna Widy 